\title{
RELAÇÕES ECONÔMICAS ENTRE AMÉRICA LATINA E CARIBE E CHINA E SEUS IMPACTOS NA INTEGRAÇÃO REGIONAL (2001-2016)
}

\author{
Thauan Santos ${ }^{1}$ \\ Alana Camoça \\ Bernardo Salgado Rodrigues 3
}

\begin{abstract}
Este artigo fornece uma análise da presença e influência chinesas na América Latina e no Caribe, afetando os processos de integração regional existentes na região. Partimos de uma breve análise qualitativa, enfatizando o papel da influência estrangeira na integração regional e destacando como o plano de expansão chinês afeta o caso da integração latino-americana. Em seguida, é realizada uma análise quantitativa crítica das transações entre América Latina e Caribe (LAC) e China, analisando importações/exportações, acordos preferenciais comerciais (APCs) e investimento estrangeiro direto (IED). Os dados compreendem o período 2001-2016 e provêm da United Nations Commodity Trade Statistics Database (UN Comtrade), World Integrated Trade Solutions (WITS), China-Latin America Finance Database e China Global Investment Tracker. Concluindo, destacamos a crescente influência chinesa na região da LAC, ressaltando que 0 estreitamento bilateral dos países latino-americanos com a China tem um impacto indireto e adverso sobre a integração regional.
\end{abstract}

Palavras-chave: integração regional; América Latina e Caribe; China; relações comerciais e econômicas.

\section{LATIN AMERICA AND CARIBBEAN-CHINA ECONOMIC RELATIONS AND THEIR IMPACTS ON REGIONAL INTEGRATION (2001-2016)}

The article provides an analysis of the Chinese presence and influence in Latin America and the Caribbean (LAC), and how it affects regional integration processes that exist in the region. We start from a brief qualitative analysis, stressing the role of foreign influence on regional integration, highlighting how the Chinese expansion plan affects the case of Latin American integration. Then, a critical quantitative analysis of the transactions between LAC-China is carried out, analyzing imports/exports, preferential trade agreements (PTA), and foreign direct investment (FDI). The data comprises the 2001-2016 period and were retrieved from the United Nations Commodity Trade Statistics Database (UN Comtrade), World Integrated Trade Solutions (WITS), China-Latin America Finance Database, and China Global Investment Tracker. In conclusion, we highlight the growing Chinese influence in the Latin America region, emphasizing that the bilateral narrowing of Latin American countries with China has an indirect and adverse impact on regional integration.

Keywords: regional integration; Latin America and the Caribbean; China; trade and economic relations.

\footnotetext{
1. Professor adjunto do Programa de Pós-Graduação da Escola de Guerra Naval (PPGEM/EGN); coordenador do Grupo Economia do Mar (GEM); e pesquisador do Conselho Latino-Americano de Ciências Sociais (CLACSO). Doutor em planejamento energético (engenharia de produção) pelo Instituto Alberto Luiz Coimbra de Pós-Graduação e Pesquisa de Engenharia da Universidade Federal do Rio de Janeiro (PPE/COPPE/UFRJ). E-mail:<thauan@marinha.mil.br>. Orcid: <https://orcid.org/0000-0002-4001-4322>.

2. Doutora pelo Programa de Pós-Graduação em Economia Política Internacional da Universidade Federal do Rio de Janeiro (PEPI/UFRJ) e pós-doutora em ciências militares na Escola de Comando e Estado-Maior do Exército (ECEME). E-mail: <alanacamoca@gmail.com>. Orcid:<https://orcid.org/0000-0003-0330-3368>.

3. Doutor pelo PEPI/UFRJ. E-mail: <bernardosalgado90@gmail.com>. Orcid: <https://orcid.org/0000-0002-6439-8359>.
} 


\title{
RELACIONES ECONÓMICAS ENTRE AMÉRICA LATINA Y EL CARIBE CON CHINA Y LOS IMPACTOS EN LA INTEGRACIÓN REGIONAL (2001-2016)
}

\begin{abstract}
En este artículo se analiza como la presencia e influencia china en América Latina y el Caribe (LAC) afecta a los procesos de integración regional existentes en la región. Comenzamos con un breve análisis cualitativo, enfatizando el papel de la influencia extranjera en la integración regional, destacando cómo el plan de expansión chino afecta a la integración latinoamericana. A continuación, se realiza un análisis cuantitativo crítico de las transacciones de LAC-China, analizando las importaciones/exportaciones, los acuerdos comerciales preferenciales (ACP) y la inversión extranjera directa (IED). Los datos comprenden el período 2001-2016 y proceden de United Nations Commodity Trade Statistics Database (UN Comtrade), World Integrated Trade Solutions (WITS), China-Latin America Finance Database, y China Global Investment Tracker. En conclusión, destacamos la creciente influencia china en la región de América Latina, poniendo de relieve que el estrechamiento de las relaciones bilaterales de los países latinoamericanos con China tiene un impacto indirecto y adverso en la integración regional.
\end{abstract}

Palabras clave: integración regional; América Latina y el Caribe; China; relaciones comerciales y económicas.

JEL: F10; F21; F59; 053; 054.

DOl: http://dx.doi.org/10.38116/rtm24art4

Data de envio do artigo: 17/6/2020. Data de aceite: 17/9/2020.

\section{INTRODUÇÃO}

"Quando todas as flores participam da florada a primavera é mais bonita", disse Xi Jinping na cerimônia de abertura da primeira Expo de Importação Internacional da China, que ocorreu em Shangai, em 2018 (Hui, 2018, tradução nossa). O presidente chinês, referenciando-se a um antigo ditado do seu país, informava aos espectadores sobre a necessidade de promover um mundo cooperativo que levasse adiante propostas guiadas pela perspectiva da economia liberal baseada nos pressupostos dos benefícios da globalização e da interdependência entre os países. O discurso chinês, que enfatiza o livre-comércio, a cooperação e a complementaridade das economias mundiais, relaciona-se com as estratégias e os esforços que o governo vem empregando em nível internacional no século XXI, sobretudo quando analisamos sua aproximação com países da América Latina e da África, entre outros.

A ascensão econômica chinesa, além de sua expansão nos dois continentes durante este século, está desafiando a ordem mundial, pois, ao mesmo tempo que produz oportunidades para alguns países, também gera desafios para outros. Relativamente às regiôes em questão, destaca-se que, particularmente no âmbito da América Latina e do Caribe, existem diferentes iniciativas e processos de integração regional, que ganharam fôlego nos anos 1990, com o Mercado Comum do Sul (Mercosul) (1990) e o Acordo de Livre Comércio das Américas (Nafta), assim como iniciativas que datam dos anos 2000, como a União de 
Naçôes Sul-Americanas (Unasul) e a Aliança Bolivariana para os Povos de Nossa América (Alba). O que se identifica neste artigo, no entanto, é a necessidade de se analisar o contexto político-econômico externo, para além da conjuntura regional, a fim de se entender o movimento de ups and downs que a integração regional da América Latina vem apresentando no século XXI.

Sendo assim, à luz da perspectiva da integração regional, este texto busca investigar os efeitos da presença chinesa na América Latina e no Caribe por meio de uma pesquisa quantitativa e qualitativa, analisando dados sobre o comércio, os acordos de livre-comércio e os investimentos chineses na região entre 2001 e 2016. Para tal, a seção a seguir fará uma breve apresentação da relevância da integração regional para se compreender o desenvolvimento econômico da América Latina. Em seguida, analisa-se a relação entre a América Latina e o Caribe (LAC, sigla em inglês) e a China por meio de dados quantitativos, utilizando como variáveis: i) o comércio de mercadorias; ii) os acordos preferenciais comerciais (APCs); e iii) os investimentos estrangeiros diretos (IEDs). Os dados compreendem o período 2001-2016 e provêm da United Nations Commodity Trade Statistics Database (UN Comtrade), World Integrated Trade Solutions (WITS), China-Latin America Finance Database e China Global Investment Tracker.

Busca-se, portanto, analisar esses pontos para contribuir com o debate sobre os impactos da ascensão e projeção internacional da China sobre países em desenvolvimento, particularmente considerando como as relações LAC-China afetam os processos de integração regional, assim como o desenvolvimento socioeconômico da região. Por fim, são feitas algumas conclusóes, que evidenciam a crescente participação e influência chinesa na regiấo latino-americana e caribenha.

\section{A INTEGRAÇÃO REGIONAL LATINO-AMERICANA E O DESENVOLVIMENTO ECONÔMICO DA REGIÃO}

Segundo Padula (2010, p. 44), as primeiras contribuições sistematizadas da teoria das relaçôes internacionais à teoria da integração regional foram realizadas por Karl Deutsch e David Mitrany, destacando a "primeira onda", iniciada após a Segunda Guerra Mundial, e que teve a experiência da integração europeia como seu ícone, na década de 1950 (op. cit., p. 17-18). Representava que Estados competidores no sistema internacional poderiam cooperar em áreas específicas, apoiando o argumento da integraçáo, o que viria a ser relacionado com a noção de funcionalismo e goal-oriented issues (agendas temáticas orientadas) (Santos, 2014). Sem dúvida, a influência europeia inspirou e moldou parcialmente o design institucional dos arranjos e iniciativas de integração na LAC, criando uma série de desafios à adequação do modelo europeu à regiáo. 
Desde a sua incorporação ao sistema mundial, no século XVI, a América Latina enfrentou obstáculos políticos e físicos à sua integração, "o que acarretou, justamente, um baixo grau de interdependência entre as economias nacionais, ainda hoje marcadas por grande extroversão econômica” (Almeida, 2006, p. 15). Entretanto, reconhecemos que "sem a integração sul-americana, as economias locais podem ficar expostas à uma marginalização global” (Kelly, 1997, p. 159, tradução nossa), o que vem intensificando a "tomada de consciência de que pequenos países isolados não poderão fazer face aos crescentes problemas que são colocados pela superação do subdesenvolvimento" (Furtado, 1970, p. 290).

Como afirmam Traspadini e Stedile (2011, p. 224), a integração econômica (latino-americana) é pré-requisito indispensável para se integrar à economia mundial, evitando o isolamento e a dispersão. Para que haja uma maior institucionalidade da integraçáo e sua relação com o aprofundamento dos processos, é necessário estimular a reflexão sobre os impactos político-econômicos da cooperação nos espaços sul-americanos, assim como sobre as perspectivas de longo prazo desse processo num cenário globalizado. Dessa maneira, entende-se que a integração regional da região não deve ser compreendida como um fim em si mesma; pelo contrário, deve ser interpretada como uma estratégia de desenvolvimento regional conjunto, de redução das assimetrias intrarregionais e, em última instância, de reinserção no sistema internacional.

Os aspectos positivos da integração são percebidos pelos diferentes países que fazem parte do concerto, em maior ou menor medida. De acordo com Santos (2018), pode-se citar, entre outros, os efeitos que se seguem:

- aproveitamento das economias de escala;

- influência nas expectativas de investimento nacional e estrangeiro;

- redução dos custos de transação;

- efeitos sobre as taxas de crescimento;

- possível estabelecimento de uma arquitetura financeira regional;

- incorporação do progresso científico-técnico e da articulação produtiva;

- elevação da produção e da produtividade;

- favorecimento da padronização de normas e regulaçóes;

- estabelecimento de negociaçóes ou de consultas prévias a fim de evitar represálias;

- desconstrução das assimetrias regionais;

- intensificaçáo da complementaridade produtiva; 
- ampliação da participação de componentes sociais;

- impulsão de desenvolvimento com equidade;

- consecução de projetos de infraestrutura física e energética;

- criação de mecanismos de defesa militar e econômica; e

- inserção mundial mais soberana com a elevação do poder de barganha internacional.

Fica evidente, assim, que as interfaces da integração regional vão muito além da questão econômica per se, tangenciando agendas mais amplas, como a de direitos humanos, cultura e demais variáveis de natureza social.

Dessa forma, um denominador comum acerca da sua concepção teórica da integração para a LAC é um projeto conjunto de tomada de decisóes com a finalidade de superar desafios políticos, econômicos, físicos e sociais entre países vizinhos (ou não) que colaboram na gestão de recursos e bens comuns. Trata-se de um instrumento, uma ferramenta, um meio para se desvencilhar da condição de subdesenvolvimento e, consequentemente, alavancar uma projeção de poder regional em nível internacional. No caso latino-americano especificamente, congrega o fortalecimento da posiçâo internacional da regiáo no sistema mundial, o enfrentamento da desigualdade/desconstrução das assimetrias regionais, a construção de uma identidade regional, a autodeterminação entre os países.

A possibilidade da integração regional para os países da LAC pode ser constatada a partir da correlação de interesses mútuos e recíprocos. Essa convergência é profícua e duradoura na medida em que a integração regional pode ser intensificada ao longo do tempo. Em qualquer projeto desse tipo, os objetivos finais são delineados como uma meta geopolítica, de redução da dependência e da vulnerabilidade externa. Seja em termos de segurança, desenvolvimento, poder internacional ou identidade, a integração regional busca confluir os interesses e resolver os desafios particulares e coletivos dos países integrantes - que não poderiam ser sanados isoladamente -, assim como em sua relaçáo com as potências hegemônicas, levando a uma mudança do status quo no sistema internacional.

Como pretendemos evidenciar ao longo deste artigo, o avanço desse processo não depende exclusivamente de variáveis relativas à conjuntura político-econômica regional, uma vez que é influenciado direta e/ou indiretamente pela relação desses mesmos países com o resto do mundo. Nesse sentido, destacamos que diante do crescimento da relevância chinesa no mundo, especialmente no que compete à questão dos fluxos comerciais e de investimento, o processo de integração latino-americano tem sido impactado por esses novos fluxos - para além da própria alteração do cenário regional, impactando 
negativamente a vontade política de os países latino-americanos aprofundarem suas iniciativas regionais.

As seçóes seguintes analisam, portanto, dados de comércio, acordos comerciais e investimentos entre os países da região e da China. Destaca-se a relação crescentemente assimétrica entre América Latina e Caribe e China no que compete a esses fluxos e analisa-se como, de modo indireto, eles têm contribuído para mitigar a relevância das iniciativas regionais. Consequentemente, como se tem presenciado na região, a agenda da integração regional se esvazia nas diferentes regióes da América, sendo associada a uma pauta politizada e, por extensão, questionável, criticada e cada vez mais sem relevância.

\section{RELAÇÕES COMERCIAIS ENTRE CHINA E LAC}

Relativamente à questão da dependência LAC-China, existe há décadas na região (desde os anos 1950) um debate conceitual acerca da relação causal entre comércio, crescimento econômico e desigualdade, sem um consenso sobre as causas e direçóes dessas relaçóes (Peters, 2013). Do ponto de vista da China, a busca por objetivos estratégicos nacionais inclui maior cooperação econômica e política de longo prazo, incluindo relaçóes comerciais com a LAC (Melo e Amaral Filho, 2015; Harris, 2015).

A participação do top 5 destinos das exportaçóes chinesas para a LAC (gráfico 1) aumenta entre 2001 (73,3\%) e 2016 (77,3\%) - crescimento de 4 pontos percentuais (p.p.) -, tendo alcançado seu máximo em 2010 (79,2\%). Em 2016, os principais destinos foram México (28,6\%), Brasil (19,4\%) e Chile (19,4\%), revelando uma certa homogeneidade entre o peso relativo dos principais países latino-americanos nas importaçóes chinesas. Percebe-se, contudo, que a LAC representa, em média, 4,8\% do destino das exportaçôes chinesas, aumentando entre 2001 (3,1\%) e 2016 (5,4\%), tendo alcançado seu máximo em 2012 (6,6\%).

A LAC não está entre os principais destinos das exportaçóes chinesas. Em 2016, os principais destinos foram respectivamente Estados Unidos (19,2\%), Hong Kong (12,1\%) e Japão (5,9\%), totalizando 38,2\%. Convém destacar, contudo, que esse valor alcançava 54,8\% em 2001, o que está alinhado à diversificação de parceiros comerciais do país (going global strategy). Em 2016, os países da América Latina que protagonizaram os destinos das exportaçôes chinesas foram México (em 17으, com 1,8\%), Brasil (24oㅜ 1,4\%), Chile $\left(34^{\circ}, 0,6 \%\right)$, Argentina $\left(43^{\circ}, 0,3 \%\right)$ e Colômbia (44oㅜ 0,3\%), totalizando $3,9 \%$. Esse valor alcançava apenas $1,8 \%$ em 2001, tendo dobrado no período em questão. Portanto, na contramão da diversificação de parceiros regionais, observa-se que a LAC aumentou sua participação no destino das exportaçóes chinesas entre 2001-2016. 


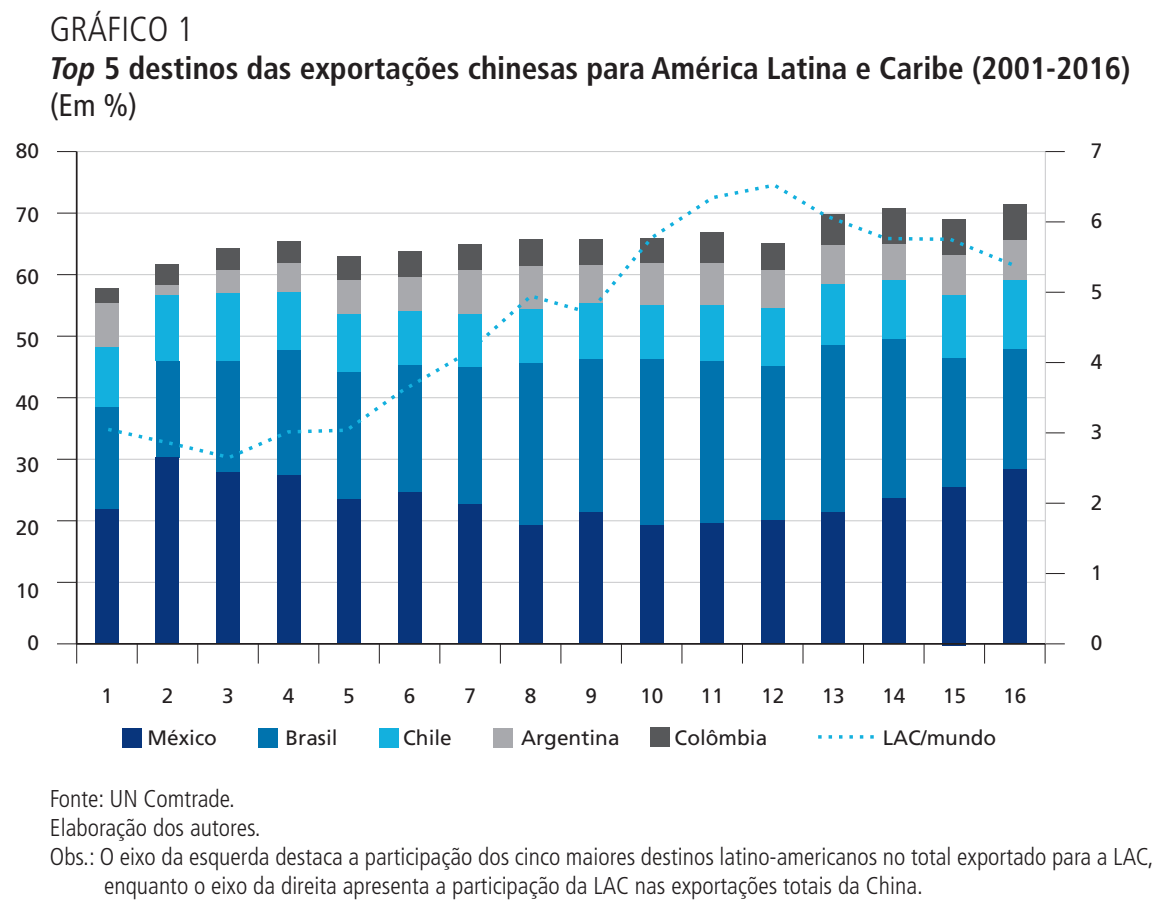

A tabela 1 apresenta a evolução das exportações chinesas para a LAC, destacando os principais produtos. Percebe-se um aumento entre 2001 (US\$ 8,2 bilhôes) e 2016 (US\$ 113,2 bilhôes), correspondendo a um aumento acumulado de quase catorze vezes seu valor original. Além disso, entre 2011-2016, o top 5 produtos exportados para a região passaram de 4,8\% para $17,1 \%$, evidenciando também uma concentração da pauta.

Os produtos 8471, 8517 e 9013 também se encontram entre os principais produtos chineses importados pelo mundo, correspondendo a $16,9 \%$ da pauta exportadora em 2016 (frente a 6,5\%, em 2001). Isso revela uma inserção latino-americana no comércio internacional alinhada aos produtos importados pelo resto do mundo. Entre os principais produtos chineses exportados para América Latina, destacam-se produtos de média e alta tecnologia. Em 2016, agregando-os por setores, encontram-se maquinários e produtos relacionados com eletricidade $(53,1 \%)$, diversas $(9,7 \%)$, têxteis e de vestuário $(7,8 \%)$ e produtos químicos (6,5\%) (González, 2018).

A participação do top 5 origens das importaçōes chinesas da América Latina (gráfico 2) aumenta entre 2001 (73,4\%) e 2016 (82,3\%) - crescimento de 8,9 p.p. -, quando alcança seu máximo. Em 2016, as principais origens são Brasil $(44,8 \%)$, Chile $(18,2 \%)$ e México $(10,1 \%)$, revelando uma grande assimetria 
entre o peso relativo dos principais países latino-americanos nas importaçóes chinesas. Percebe-se, contudo, que a América Latina representa, em média, 5,3\% da origem das importações chinesas, aumentando entre 2001 (2,7\%) e 2016 (6,4\%), tendo alcançado seu máximo em 2012 (6,9\%).

\section{TABELA 1}

Top 5 produtos das exportações chinesas para América Latina e Caribe e total exportado para região (2001-2016)

$(\mathrm{Em} \%)$

\begin{tabular}{lcccccccccccccccc}
\hline Código do produto & 2001 & 2002 & 2003 & 2004 & 2005 & 2006 & 2007 & 2008 & 2009 & 2010 & 2011 & 2012 & 2013 & 2014 & 2015 & 2016 \\
\hline $8517^{1}$ & 0,7 & 0,5 & 0,7 & 1,0 & 1,6 & 1,7 & 5,9 & 6,7 & 7,3 & 6,0 & 6,3 & 5,6 & 6,8 & 6,3 & 6,3 & 6,8 \\
$9013^{2}$ & 0,1 & 0,0 & 0,3 & 0,5 & 0,8 & 1,1 & 2,3 & 2,7 & 3,9 & 3,7 & 3,4 & 3,4 & 3,5 & 3,1 & 3,1 & 3,6 \\
$8471^{3}$ & 2,7 & 2,3 & 2,3 & 2,9 & 2,9 & 3,5 & 2,8 & 2,8 & 4,3 & 4,3 & 3,8 & 3,2 & 3,5 & 3,4 & 2,9 & 2,9 \\
$8708^{4}$ & 0,4 & 0,5 & 0,5 & 0,6 & 0,9 & 1,0 & 1,1 & 1,0 & 1,1 & 1,1 & 1,1 & 1,2 & 1,4 & 1,6 & 1,7 & 2,0 \\
$8528^{5}$ & 1,0 & 1,1 & 0,8 & $\mathbf{0 , 8}$ & 1,0 & 1,4 & $\mathbf{2 , 3}$ & $\mathbf{1 , 9}$ & $\mathbf{1 , 8}$ & $\mathbf{2 , 1}$ & $\mathbf{1 , 7}$ & $\mathbf{1 , 5}$ & $\mathbf{1 , 5}$ & $\mathbf{1 , 5}$ & 1,4 & 1,8 \\
Total (US\$ bilhões) & $\mathbf{8 , 2}$ & $\mathbf{9 , 4}$ & $\mathbf{1 1 , 7}$ & $\mathbf{1 8 , 0}$ & $\mathbf{2 3 , 4}$ & $\mathbf{3 5 , 7}$ & $\mathbf{5 1 , 3}$ & $\mathbf{7 1 , 2}$ & $\mathbf{5 6 , 6}$ & $\mathbf{9 1 , 2}$ & $\mathbf{1 2 1 , 0}$ & $\mathbf{1 3 4 , 3}$ & $\mathbf{1 3 3 , 2}$ & $\mathbf{1 3 5 , 0}$ & $\mathbf{1 3 1 , 2}$ & $\mathbf{1 1 3 , 2}$ \\
\hline
\end{tabular}

Fonte: UN Comtrade.

Elaboração dos autores.

Notas: ${ }^{1}$ Aparelhos telefônicos, inclui telefones para redes celulares ou para outras redes sem fio; outras.

${ }^{2}$ Dispositivos de cristais líquidos que não constituam artigos previstos mais especificamente em outras categorias.

${ }^{3}$ Máquinas automáticas para processamento de dados e suas unidades; leitores magnéticos ou ópticos, máquinas.

${ }^{4}$ Peças e acessórios para tratores e veículos a motor para o transporte de dez pessoas ou mais.

${ }^{5}$ Monitores e projetores que não incorporem aparelhos de recepção de televisão; aparato de recepção.

\section{GRÁFICO 2}

Top 5 origens das importações chinesas da América Latina e Caribe (2001-2016) (Em \%)

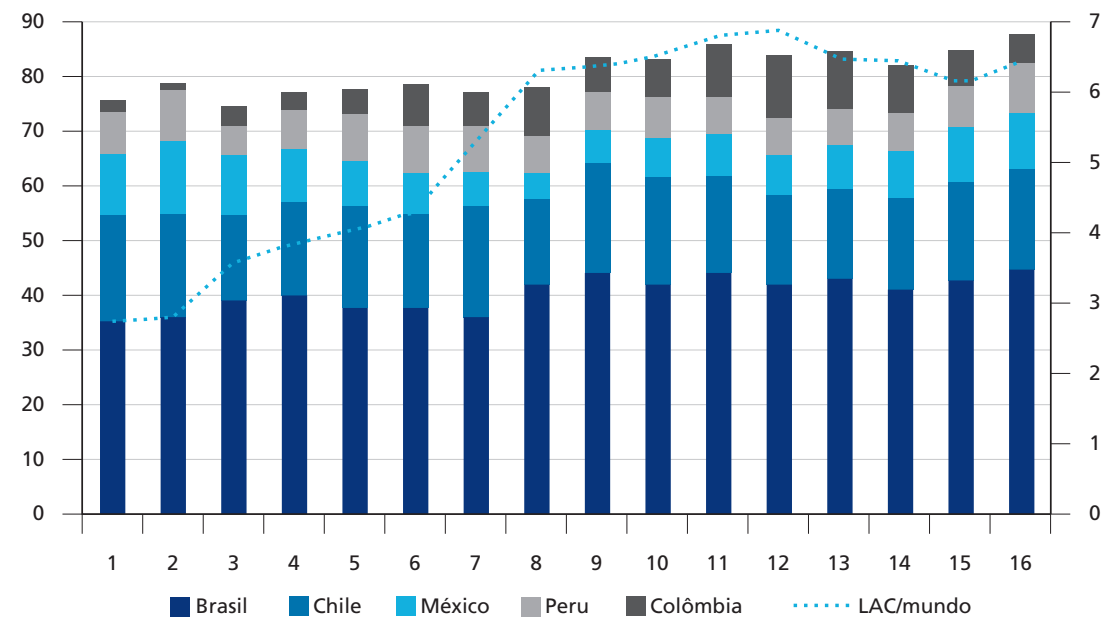

Fonte: UN Comtrade.

Elaboração dos autores.

Obs.: 0 eixo da esquerda destaca a participação das cinco maiores origens latino-americanas no total importado da LAC, enquanto o eixo da direita apresenta a participação da LAC nas importações totais da China. 
Em 2016, as principais origens dos produtos importados pela China foram, respectivamente, Coreia (10,0\%), Japão (9,2\%) e Estados Unidos (8,5\%), totalizando $27,7 \%$, valor que alcançava $37,9 \%$ em 2001, o que novamente ratifica a diversificação de parceiros comerciais do país (going global strategy) também do lado das importaçóes - ainda que em menor proporçáo que na pauta exportadora. Em 2016, os países da América Latina e Caribe que protagonizaram as origens das importaçóes chinesas foram Brasil (12ำ, 2,3\%), Chile (20ํ, 1,2\%),

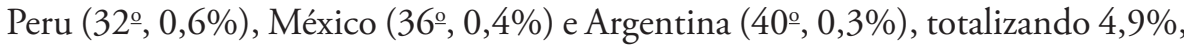
valor que alcançava apenas $1,8 \%$ em 2001, tendo quase triplicado no período em questão. Portanto, assim como no caso das exportaçóes da China para a LAC e na contramão da diversificação de parceiros regionais, destaca-se que a regiâo aumenta sua participação na origem das importaçôes chinesas entre 2001-2016.

A tabela 2 apresenta a evolução das importaçóes chinesas da LAC, destacando seus principais produtos. Nota-se um aumento entre 2001 (US\$ 8,2 bilhóes) e 2016 (US $\$ 113,2$ bilhóes), correspondendo a quase catorze vezes o valor original. Além disso, no período 2001-2016, o top 5 produtos exportados para a regiáo passaram de $4,8 \%$ para $17,1 \%$, evidenciando a concentraçáo da pauta no período analisado.

TABELA 2

Top 5 produtos das importações chinesas da América Latina e Caribe, e total importado da região (2001-2016)

$(\mathrm{Em} \%)$

\begin{tabular}{|c|c|c|c|c|c|c|c|c|c|c|c|c|c|c|c|c|}
\hline Código do produto & 2001 & 2002 & 2003 & 2004 & 2005 & 2006 & 2007 & 2008 & 2009 & 2010 & 2011 & 2012 & 2013 & 2014 & 2015 & 2016 \\
\hline $1201^{1}$ & 24,0 & 18,2 & 21,5 & 16,7 & 17,3 & 14,0 & 14,2 & 18,7 & 14,5 & 15,1 & 14,3 & 15,3 & 19,1 & 18,6 & 21,2 & 19,0 \\
\hline $2601^{2}$ & 12,4 & 10,9 & 10,4 & 16,2 & 17,4 & 18,3 & 20,8 & 23,9 & 22,4 & 22,9 & 25,7 & 21,1 & 20,6 & 16,6 & 13,3 & 14, \\
\hline $2709^{3}$ & 0,5 & 0,0 & 1,2 & 3,4 & 4,5 & 10,4 & 8,0 & 11,0 & 8,1 & 11,4 & 13,2 & 15,8 & 14,8 & 17,4 & 14,3 & 13, \\
\hline $2603^{4}$ & 5,6 & 4,0 & 4,4 & 6,2 & 8,7 & 10,0 & 10,3 & 7,8 & 6,3 & 7,7 & 6,6 & 7,6 & 9,0 & 8,8 & 10,1 & 12,8 \\
\hline $7403^{5}$ & 8,2 & 10,9 & 8,5 & 9,3 & 8,1 & 6,7 & 10,4 & 7,5 & 12,8 & 12,2 & 10,3 & 9,2 & 7,4 & 8,3 & 8,5 & 7,8 \\
\hline Total (US\$ bilhões) & 6,7 & 8,3 & 14,9 & 21,7 & 26,7 & 34,1 & 51,0 & 71,4 & 64,1 & 91,1 & 118,6 & 125,1 & 126,4 & 126,0 & 102,9 & 102, \\
\hline $\begin{array}{l}\text { Fonte: UN C } \\
\text { Elaboração } \\
\text { Notas: }{ }^{1} \text { Soja } \\
{ }^{2} \text { Min } \\
{ }^{3} \text { Petr } \\
{ }^{4} \text { Min }\end{array}$ & $\begin{array}{l}\text { auto } \\
\text { ja o } \\
\text { s e c }\end{array}$ & $\begin{array}{l}\text { res. } \\
\text { unão } \\
\text { tonce } \\
\text { leos } \\
\text { tonce }\end{array}$ & trado & $\mathrm{m}$ & ais & tum & oso & $\begin{array}{l}\text { e fer } \\
\text { rus. }\end{array}$ & 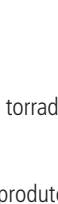 & & & & & & & \\
\hline
\end{tabular}

Os produtos 2601 e 2709 também se encontram entre os principais produtos importados pela China de maneira geral (não restrita à regiáo da LAC), correspondendo a $14,7 \%$ da pauta importadora em 2016 (frente a 5,8\%, em 2001). Isso revela uma inserção latino-americana no comércio internacional por meio das exportaçóes para a China, o que corrobora uma demanda global 
chinesa desses produtos, inclusive do resto do mundo. Entre esses produtos destacam-se soja, óleo de petróleo bruto, minérios e concentrados de ferro, bem como minérios e concentrados de cobre, que tiveram poucas variaçóes nos preços após o pico de 2014 (Ray e Wang, 2019), mais conhecido pelo boom das commodities - o que justifica a queda do valor total exportado para a China entre 2014 e $2015(-18,3 \%)$.

De maneira agregada por setores, destacam-se nas exportaçōes da LAC para a China, em 2016, minerais $(30,5 \%)$, vegetais $(26,3 \%)$, metais $(13,1 \%)$ e combustíveis (8,0\%) (González, 2018). Além disso, na contramão do que ocorre com o caso das exportações chinesas para América Latina, as exportações da LAC para a China vêm reduzindo seu conteúdo tecnológico no período analisado (Estevadeordal, Moreira e Kahn, 2014; Peters, 2013), levantando um debate regional acerca da desindustrialização dos países da América Latina e da reprimarização de sua pauta exportadora (Jenkins, 2015; Curado, 2015).

Com base na tabela 3, percebe-se que existe uma dependência assimétrica entre LAC e China no que se refere à balança comercial no período analisado (2001-2016). O saldo da balança comercial chinesa com a LAC é negativo pontualmente na série histórica analisada (2003, 2004, 2005, 2008 e 2009). Por sua vez, o saldo da balança comercial da América Latina com a China é sistematicamente negativo durante o período analisado. Destaca-se, contudo, que o superavit da balança comercial chinesa com a LAC aumenta mais de sete vezes entre 2001 (US\$ 1,5 bilhão) e 2016 (US\$ 10,8 bilhôes), enquanto o deficit da balança comercial da LAC com China aumenta mais de dezesseis vezes no mesmo período (-US\$ 5,1 bilhôes para -US\$ 83,0 bilhôes), reforçando a assimetria da relação bilateral.

TABELA 3

Saldo da balança comercial da China/LAC com LAC/China (2001-2016)

(Em US\$ bilhões)

\begin{tabular}{lcccccccccccccccc}
\hline & 2001 & 2002 & 2003 & 2004 & 2005 & 2006 & 2007 & 2008 & 2009 & 2010 & 2011 & 2012 & 2013 & 2014 & 2015 & 2016 \\
\hline China com LAC & 1,5 & 1,1 & $-3,1$ & $-3,6$ & $-3,3$ & 1,6 & 0,3 & $-0,2$ & $-7,6$ & 0,1 & 2,3 & 9,2 & 6,8 & 9,0 & 28,2 & 10,8 \\
LAC com China & $-5,1$ & $-6,0$ & $-6,8$ & $-13,6$ & $-17,3$ & $-31,6$ & $-36,0$ & $-57,9$ & $-35,4$ & $-53,3$ & $-66,5$ & $-83,0$ & $-85,6$ & $-87,0$ & $-98,1$ & $-83,0$ \\
\hline Fonte: UN Comtrade. & & & & & & & & & & & & & &
\end{tabular}

O gráfico 3 destaca a participação da China/LAC no comércio total, em percentual. Mais uma vez, a assimetria na relação entre as regióes analisadas se faz presente, dada a maior participação da China nas exportaçôes/importaçôes da LAC que o contrário (Ray e Wang, 2019). Pode-se dizer, inclusive, que a relaçáo de dependência muda no período analisado (2001-2016), uma vez que, em 2001, a participação da LAC nas exportaçôes chinesas era de 
3,1\% (US\$ 8,2 bilhóes) e da China nas exportaçóes da LAC era de apenas 1,5\% (US \$ 5,3 bilhōes). Relativamente às importaçōes, a participação era semelhante no mesmo ano, sendo de 2,7\% (US\$ 6,7 bilhóes) e 2,8\% (US\$ 10,4 bilhóes), respectivamente. Em 2016, contudo, a relação de dependência se altera, com a participação da LAC nas exportaçóes chinesas crescendo apenas para 5,4\% (US\$ 113,2 bilhóes), enquanto a participação da China nas exportaçóes da LAC chega a 9,1\% (US\$ 80,4 bilhôes). O cenário das importaçōes é ainda mais grave, com a participação da LAC nas importações chinesas chegando a 6,4\% (US\$ 102,4 bilhôes), enquanto as importaçóes da LAC de produtos chineses alcançam 17,9\% (US\$163,4 bilhôes).

GRÁFICO 3

Participação da China/LAC no comércio total (2001-2016)

(Em \%)

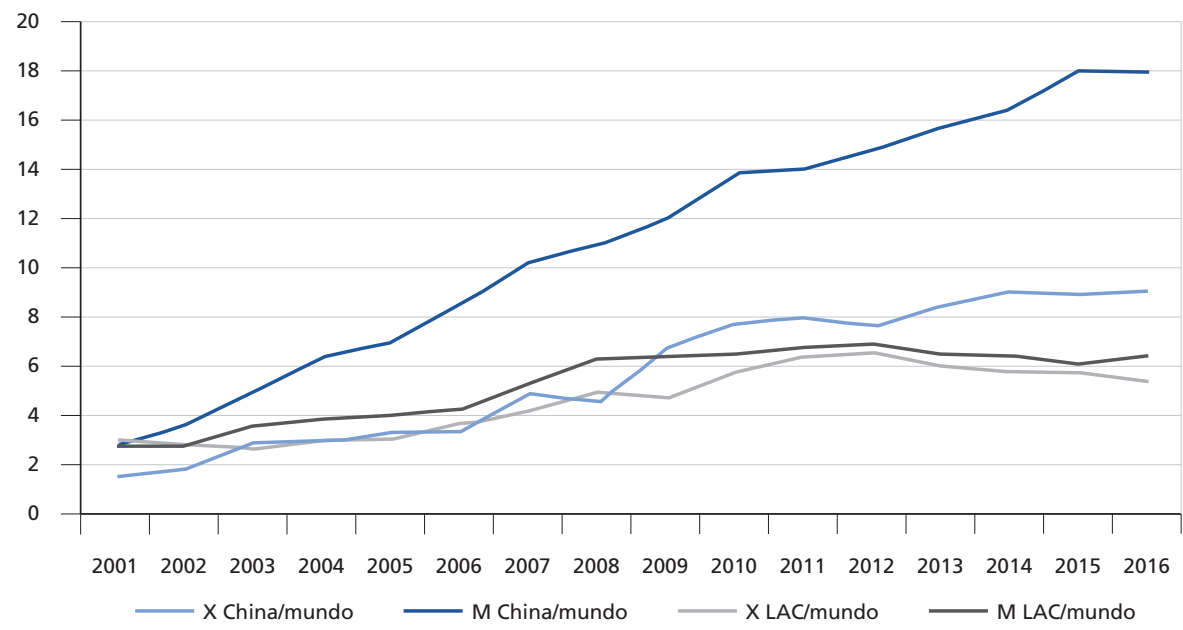

Fonte: UN Comtrade.

Elaboração dos autores.

Obs.: $\mathrm{X}=$ exportações; $\mathrm{M}=$ importações.

De maneira geral, no período analisado, a China se tornou o segundo parceiro comercial da LAC, compensando a perda relacionada aos Estados Unidos. Em 2001, os principais destinos das exportaçóes da LAC extrarregião eram Estados Unidos (55,2\%), Japão (2,1\%) e Holanda (2,0\%); em 2016, passaram a ser Estados Unidos (45,1\%), China (9,1\%) e Holanda (2,3\%) evidenciando, assim, que o top 3 destinos extrarregiâo se compensam, já que caem marginalmente de $59,3 \%$ para $56,5 \%$ do total exportado pela LAC.

Do lado das importaçóes, destacam-se, em 2001, Estados Unidos (45,8\%), Japão (4,5\%) e Alemanha (4,2\%). Em 2016, por sua vez, Estados Unidos $(32,4 \%)$, China $(17,9 \%)$ e Alemanha $(4 \%)$. De maneira análoga às exportaçôes 
da LAC, o top 3 origem extrarregião das importaçóes caem de 54,5\% para 54,3\% do total importado pela LAC. Mais do que uma relação de complementaridade ou dependência (Cypher e Wilson, 2015), o que se identifica, com base nos dados comerciais, é uma crescente relação bilateral assimétrica entre LAC e China (Jenkins, 2012).

Diante dessa relevância crescente da China nas transaçóes econômicas com diferentes países da LAC, percebemos, consequentemente, a queda relativa dos vizinhos nas relações econômicas de determinados países da região, como é o caso do Brasil, por exemplo. Sendo assim, mais do que buscar estreitar relaçóes preexistentes com os vizinhos da LAC, diferentes países da região têm se aproveitado e se beneficiado de certas relaçóes comerciais com a China. Como destacado inicialmente, isso corrobora a percepção de que a integração regional já não representa o pilar de desenvolvimento de outrora, marginalizando a importância do tema na LAC.

\section{ACORDOS PREFERENCIAIS DE COMÉRCIO: 0 DRAGÃO E O BILATERALISMO}

$\mathrm{O}$ apetite do dragão chinês pelos mercados latino-americanos incentivou a realizaçáo de acordos preferenciais de comércio, particularmente desde o início do século XXI. Esses acordos sáo uma "faca de dois gumes", em que, isocronicamente, os países se expóem ao aumento da concorrência com outros países, os quais, em contrapartida, lhes outorgam benefícios comerciais e obtêm maiores facilidades para ingressar nos mercados dinâmicos dos países associados (Sevares, 2015). Nesse sentido, países latino-americanos têm se aproximado cada vez mais de países asiáticos, com o intuito de participar de seus mercados e de suas cadeias de valor, as mais dinâmicas do mundo. Todavia, apesar de a presença chinesa na LAC se expandir desde o início do século XXI, esse processo náo é homogêneo, simétrico e nem uniforme, como foi observado tanto no tocante ao caso do comércio como no que se refere às questôes de IED.

Atualmente existem três APCs firmados entre a China e países latino-americanos, sendo eles com: i) Chile (2006 e 2016); ii) Peru (2010); e iii) Costa Rica (2011). A maior parte dessas negociaçóes dos APCs teve como intuito o debate sobre a extensão da cobertura de produtos para linhas tarifárias liberalizadas, prazos para liberalização e a redução de políticas que seriam consideradas mais prejudiciais às relaçôes econômicas entre os países, como será analisado a seguir.

Concatenando dados mais específicos do comércio da China com os países latino-americanos que possuem APCs ou que estabeleceram acordos no período entre 2001-2016, é possível observar uma expansão nas dinâmicas comerciais e algumas semelhanças entre os acordos. O primeiro acordo de livre comércio firmado entre a China e algum país latino-americano foi o chileno, que foi 
assinado em 2005 e entrou em vigor no ano de 2006, englobando inicialmente a área de trocas comerciais. No acordo, estipulava-se que seriam removidas as tarifas de mais de $97 \%$ dos produtos de ambas as naçóes em até dez anos (Dezan Shira and Associates, 2005). A principal vantagem em termos de quantidade de produtos sem tarifa, contudo, foi para o Chile, que garantiu a eliminação imediata de $92,01 \%$ das tarifas de suas exportaçôes e removeu apenas de $50 \%$ das importaçóes chinesas (Rosales e Kuwayama, 2012).

TABELA 4

APCs da China com países latino-americanos

\begin{tabular}{lccc}
\hline Parceiro comercial & Grau de integração & Escopo & Entrada em vigor \\
\hline \multirow{2}{*}{ Chile } & Acordo de Livre Comércio & Bens & $1 / 10 / 2006$ \\
& & Serviços & $1 / 8 / 2010$ \\
\hline \multirow{2}{*}{ Peru } & Acordo de Livre Comércio & Serviços & $1 / 3 / 2010$ \\
& & Bens & \\
\hline \multirow{2}{*}{ Costa Rica } & Acordo de Livre Comércio & Investimentos & $1 / 8 / 2011$ \\
& & Bens & $1 / 8 / 2011$ \\
\hline
\end{tabular}

Fonte: Foreign Trade Information System (Sice). Disponivel em: <http://www.sice.oas.org/agreements_e.asp>. Elaboração dos autores.

Em 2008, foi assinado um acordo suplementar incorporando também o comércio de serviços entre os países - implementado em 2010 - e, posteriormente, rodadas de negociaçóes sobre um acordo de investimentos se desenvolveram ao longo dos anos. Desde 2015, ocorreram conversas sobre a atualizaçáo do acordo preferencial entre ambos os países e, em 2017, foi assinado um novo acordo, abrangendo áreas como comércio de bens, comércio de serviços, cooperação econômica e tecnológica, comércio eletrônico, meio ambiente e compras governamentais. ${ }^{4}$

O APC de 2005 entre ambos os países estabeleceu prazos para reduçóes tarifárias imediatas ainda no primeiro ano (ano 1), em cinco ou dez anos, no caso chileno, e imediatas, em dois, cinco ou dez anos, no caso chinês (Dezan Shire and Associates, 2005). O comércio do Chile com a China se expandiu de forma expressiva após a assinatura do acordo entre ambos os países. O governo chinês em sua página oficial, onde divulga informaçóes sobre seus acordos, apresentou, inclusive, uma propaganda sobre o consumo chinês de cobre chileno como sendo um dos elementos de recuperaçáo do país sul-americano após a crise de 2008 (China’s..., 2009).

4. Com o novo tratado, a China se comprometia a cancelar gradualmente tarifas de produtos em madeira, enquanto o Chile aboliriria tarifas em têxteis, eletrodomésticos, vestimentas e produtos do setor de açúcares, totalizando a remoção de $98 \%$ de tarifas de produtos de ambos os países (The Protocol..., 2019). 
$\mathrm{Na}$ prática, é visível que o comércio chileno com a China cresceu exponencialmente após entrada em vigor do APC em 2006, com um salto de cerca de US $\$ 5,735$ bilhóes para US $\$ 10,280$ bilhóes entre 2006 e 2007 de importações chilenas da China (+79,3\%); e de US\$ 3,102 bilhóes para US\$ 4,432 bilhōes em exportaçóes da China para o Chile $(+42,9 \%)$ (WITS, 2019). Os principais produtos chilenos exportados para a China entre 2001 e 2016 se encaixam nas categorias de minérios, escórias e cinzas (código 26) e cobre e outros produtos derivados (código 74). Esses produtos estão listados no APC entre China e Chile e representaram em 2016 cerca de 78\% das exportaçóes do Chile para a China. A maioria desses produtos teve tarifas reduzidas imediatamente após a entrada em vigor do acordo, salvo poucas exceçôes de produtos, que teriam as taxas eliminadas no prazo máximo de dez anos, como o caso de parafusos, pregos e porcas de cobre (Dezan Shire and Associates, 2005). No caso das importaçôes, os principais produtos ${ }^{5}$ exportados pela China para o Chile são máquinas, aparelhos mecânicos, reatores nucleares, caldeiras, partes (código 84) e máquinas e equipamentos elétricos e suas partes; gravadores e reprodutores de som, gravadores e reprodutores de imagens e sons da televisão e peças e acessórios desses artigos (código 85). Alguns produtos das categorias 85, contudo, como o caso do 851712 (telefones para redes celulares "telefones móveis" ou para outras redes sem fio) não entraram no acordo (Dezan Shire and Associates, 2005).

As relações comerciais entre ambos os países demonstram a relevância dos recursos naturais e de minérios para o governo chinês. Enquanto impulsionam práticas de relaçóes Norte-Sul no quadro comercial por meio da exportação de produtos manufaturados e de maior valor agregado para o Chile, a China, por sua vez, consome recursos minerais e de menor elasticidade. De fato, o Chile está longe de ser o principal parceiro comercial chinês, porém observa-se que as relaçóes do gigante asiático com o país latino-americano configuram um interesse muito mais econômico do que propriamente político. Deve-se ponderar ainda que as práticas de $\mathrm{APC}$ do Chile com países asiáticos não são novas, posto que o primeiro acordo dessa natureza entre países asiáticos e latino-americanos foi o Tratado de Livre Comércio entre Chile e Coreia do Sul em 2003. ${ }^{6}$ O Chile é o principal exportador mundial de cobre, sendo responsável por mais de $30 \%$ da produção mundial. O país, no entanto, se mantém atrasado em processos avançados de refino e fundição do mineral; por outro lado, a China se tornou uma das maiores fundidoras, refinadoras e produtoras de metais de cobre na forma de arame e lingotes (Cypher e Wilson, 2015).

5. Para observar os principais produtos exportados e importados pela China com os países latino-americanos, foi usado 0 ano-base de 2016.

6. Disponível em: <http://www.sice.oas.org/agreements_e.asp>. 
O segundo acordo preferencial de comércio chinês com um país latino-americano foi com o Peru, assinado em 2009 e que entrou em vigor em 2010, sendo aplicável no comércio de mais de $90 \%$ dos produtos de ambos os países, na área de comércio de serviços e de investimentos (Dezan Shire and Associates, 2009). Além disso, o acordo foi atualizado em 2019, com o intuito de continuar estimulando as relaçóes próximas entre ambos os países (China-Peru..., 2010).

No caso das relaçóes comerciais entre China e Peru, os produtos seguiram o cronograma de eliminação imediata (ano 1), em quatro, cinco, oito, dez, doze, quinze anos ou de forma gradual, em etapas que também variavam em relação ao tempo estimado para eliminação das tarifas. Assim como o Chile, o Peru também obteve vantagem na quantidade de produtos que sofreram a liberalização das taxas de exportaçóes para a China, garantindo, dessa maneira, a eliminação imediata de tarifas de 83,52\% de suas exportaçóes e removendo de imediato apenas 63\% das importaçôes chinesas. Esse APC envolveu produtos importantes para as relaçóes entre ambos os países, fazendo com que um dos principais produtos exportados pelo Peru, o cobre, tivesse a reduçáo imediata da tarifa (Dezan Shire and Associates, 2009).

As relaçóes entre os países foram impulsionadas no ano de assinatura do acordo, em 2009, e continuaram crescer após o tratado ter entrado em vigor. Considerando os anos de 2010 e 2011, houve um salto de cerca de US $\$ 3,549$ bilhóes para US $\$ 4,653$ bilhóes $(+31,1 \%)$ de exportaçóes da China para o Peru e de US\$ 6,368 bilhóes para US \$ 7,864 bilhōes (+23,5\%) em exportaçóes do Peru para a China. Esse crescimento mostra-se ainda mais significativo se compararmos o ano de 2009 com o ano de 2011, quando houve um aumento de cerca de US\$ 2,098 bilhóes para US\$ 4,653 bilhóes (+121,8\%) em exportaçóes da China para o Peru e de US\$ 4,323 bilhōes para US\$ 7,864 bilhôes (+81,9\%) em exportaçóes do Peru para a China (WITS, 2019).

Assim como no caso do Chile, a maioria das importaçóes chinesas vindas do Peru está inserida nas categorias 74 e 26 de produtos. Diferentemente do caso chileno, porém, em que a maioria dos produtos dessas categorias teve redução imediata de tarifas, no caso do Peru, diversos produtos entraram nas bases de diminuição de tarifas de forma gradativa, em cinco anos (por exemplo, o cobre blister - 74020010) e dez anos (alguns tipos de cobre refinado - 740710). Essa diferença pode ser um dos motivos que explicaria o aumento vertiginoso das exportações do Chile para a China (Dezan Shire and Associates, 2009).

No caso das exportaçóes chinesas para o Peru, o padrão é semelhante ao do caso chileno, sendo majoritariamente de produtos das categorias 85 (principalmente relacionados a celulares), mas também produtos como veículos que não sejam ferroviários ou elétricos, e suas partes e acessórios (vehicles other 
than railway or tramway rolling stock, and parts and accessories thereof-code 87). Diferentemente do caso chileno, contudo, os principais produtos exportados da China para o Peru, que são os do código 851712, estão inclusos no APC entre os países, com redução de tarifas ainda no primeiro ano (Dezan Shire and Associates, 2009). Assim como no caso do Chile, o Peru também possui outros acordos de livre-comércio com países asiáticos: com Japão (2011), Coreia do Sul (2012), Singapura (2008) e Tailândia (2008). ${ }^{7}$

Por fim, o último APC entre a China e um país latino-americano foi assinado em 2010, com a Costa Rica, e entrou em vigor em 2011. Assim como nos outros acordos, mais de $90 \%$ dos produtos de ambos os países estiveram sujeitos à redução de tarifas no primeiro ano e também em cinco, dez ou até quinze anos. Além disso, o acordo também atingiu o comércio de serviços de mais de quarenta setores (China-Costa Rica..., 2011). Diante do APC, a Costa Rica conseguiu a eliminação de $99,64 \%$ das tarifas de suas exportaçôes para a China, enquanto removeu $57 \%$ das tarifas imediatas.

No que diz respeito às trocas comerciais, diferentemente dos casos de Chile e Peru, os principais produtos exportados pela Costa Rica para a China estão sob os códigos 85 e 90 (ópticas, fotográficas, cinematográficas, de medição, de controle, de precisão, médicas ou cirúrgicas). Os produtos da categoria 85 exportados da Costa Rica para a China são cristais piezoelétricos montados, partes elétricas de máquinas ou aparelhos e processadores e controladores, com memória, conversores, outros circuitos; e os principais produtos exportados da China para a Costa Rica também são produtos sob o código 85 (um padrão em todos os APCs entre China e países latino-americanos) e 87 , sob o qual a maioria desses produtos entrou no APC (JWG, 2008). Atualmente, a Costa Rica conserva APCs com diversos países do mundo, como Colômbia (2013), Canadá (2001), Peru (2011), Singapura (2010) e outros.

De 2011 a 2012 houve um aumento das exportaçóes da Costa Rica para a China, com um acréscimo de US \$ 3,844 bilhôes para US\$ 5,270 bilhóes (+37\%) (WITS, 2019). Nas exportaçôes da China para a Costa Rica não houve uma mudança expressiva. Nesse sentido, considerando os três APCs, o caso da Costa Rica se mostrou pouco significativo para a expansão do comércio entre os países. De fato, desde 2007, com o reconhecimento da China por parte da Costa Rica e o rompimento das relaçóes com Taiwan, as exportaçóes do país latino-americano para a China floresceram. Desde 2012, contudo, as importaçóes chinesas da Costa Rica diminuíram, o que aponta que o APC náo estimulou o comércio e as trocas comerciais entre os dois países.

7. Disponível em: <http://www.sice.oas.org/agreements_e.asp>. 
Enquanto, em 2012, a Costa Rica representava 2,9\% das importaçóes feitas pela China, em 2016, o número passou a ser 0,46\% (WITS, 2019). Esse fato pode simbolizar o interesse e a dimensão estratégica da América do Sul, demonstrando diferenças em se pensar a atuação da China comparando a América Latina como um todo ou somente a regiăo sul-americana.

Do ponto de vista da dependência, Gallagher (2016) argumenta que as relaçôes entre China e América Latina intensificam a condição de dependência primário-exportadora sem contrapartidas de internalização de ganhos dinâmicos no longo prazo, como transferência tecnológica ou incentivo à produção de bens de maior valor agregado. Os APCs podem influenciar essa dinâmica na medida em que promovem a liberalização comercial com o fim de algumas tarifas para produtos sensíveis de ambas as economias, porém os acordos não são iguais e possuem diferenças em seus efeitos.

Em linhas gerais, como foi observado, existem características divergentes entre a relação da China com o Chile, o Peru e a Costa Rica, cada uma delas possuindo suas particularidades. Os acordos entre China e Peru e China e Chile são mais semelhantes, tendo em vista que ambos os países são os principais exportadores de cobre do mundo. No caso das relaçôes entre China e Costa Rica, manteve-se também uma relação assimétrica cujo principal produto costa-riquenho exportado são os cristais piezoelétricos montados, que são usados, por exemplo, em celulares, computadores etc. Todavia, as relaçôes entre os dois países do ponto de vista comercial e, principalmente, com relação às importaçôes chinesas da Costa Rica diminuíram vertiginosamente ao longo dos anos, apontando que o APC efetivamente não trouxe a expansão do comércio entre os países.

O principal ponto em comum em todos os APCs é a reduçáo tarifária quase imediata para mais de $80 \%$ dos produtos de países latino-americanos, excluindo algumas áreas sensíveis envolvendo trigo, açúcar, alguns tipos de roupas e outros (Rosales e Kuwayama, 2012). Já a redução/eliminação imediata de tarifas de produtos exportados da China para os países latino-americanos manteve-se abaixo de $60 \%$ dos produtos chineses. Esse fato demonstra o interesse chinês na aquisição de produtos como cobre e cristais, que são fundamentais para a produçáo de produtos de maior valor agregado.

Além disso, com relação ao comércio China-Peru e China-Chile, a necessidade de produtos primários e estratégicos que condizem com o modelo de desenvolvimento chinês de forte crescimento, com planejamento estatal combinando urbanização e industrialização, influencia as demandas chinesas por minérios e recursos naturais latino-americanos (Hiratuka, 2018; Medeiros e Cintra, 2015). Segundo Hiratuka (2018), entre 2008 e 2014, o comércio impulsionou setores envolvendo aço, alumínio, cimento, vidro e outros, devido 
aos incentivos do governo e investimentos em nível nacional e regional, o que se relaciona, por exemplo, com os investimentos chineses na refinaria de cobre, conforme foi mencionado anteriormente.

Esses pontos tiveram influência nos interesses e nas demandas chinesas por produtos latino-americanos. Consequentemente, essa relação condiz com o que podemos observar nos APCs, principalmente no caso do Chile e do Peru. Desse modo, são mantidas as assimetrias nas exportaçóes e importaçóes de produtos latino-americanos, o que influencia no interesse imediato da China pela redução de tarifas para certos produtos. Por esse motivo, enquanto as exportaçóes chinesas para a LAC são diversificadas e heterogêneas, as exportações latino-americanas para a China são altamente concentradas. Ademais, enquanto a China se estabelece na regiấo, os tratados bilaterais com alguns países da LAC podem significar a perda de capacidade de articulação dos países latino-americanos e o próprio processo de integração regional econômico.

De acordo com Sevares (2015, p. 95), o aumento da presença e capacidade de penetração de países asiáticos na América Latina impulsiona realinhamentos nas relaçóes comerciais e econômicas entre os países, bem como nas políticas regionais, aprofundando dificuldades para o desenvolvimento de programas de integraçáo regional. Isso pode ser observado quando consideramos que os APCs fortalecem as relaçóes bilaterais em detrimento das relaçóes multilaterais. Afinal, o comércio latino-americano com a China acaba sendo mais importante para os países do que o comércio intrarregional.

Um argumento contrário à ideia de que o bilateralismo chinês não seria um possível ônus para a integraçáo regional seria o fato de existirem iniciativas multilaterais entre o gigante asiático e países da América Latina. Um exemplo de um projeto multilateral que visa contribuir e incentivar as relaçôes da China com os países latino-americanos foi a criação do Fórum China-Comunidade de Estados Latino-Americanos e Caribenhos (Celac) em 2015, juntamente com o Plano de Cooperação 2015-2019 celebrado em Pequim, que teve como objetivo ampliar a área de cooperação para além da econômica, destacando segurança, agricultura, ciência, energia, cultura, educação, infraestrutura, entre outros. Todavia, o multilateralismo à maneira chinesa, presente no fórum, coloca os países da região em uma posição inferiorizada em relaçấo à China. De acordo com Carmo e Pecequilo (2016, p. 68) "é um tipo de relação na qual uma parte, a América Latina e o Caribe, faz demandas de ajuda e a outra parte, a China, ocupa a posição do ofertante da ajuda (...). O discurso chinês enfatiza a lógica horizontal da cooperação Sul-Sul, a relação não deixa de ser hierarquizada”. 


\section{OS INVESTIMENTOS CHINESES NA LAC E OS DESAFIOS DA INTEGRAÇÃO REGIONAL}

Um fator determinante de atuação da China na LAC consiste no crescimento dos IEDs - significativa ao levar em consideração as suas dimensôes qualitativas, destacadas a partir de uma lógica intertemporal que não se reduz a uma transação pontual, de liquidez imediata. Dessa forma, a China se propóe a ser um dos grandes players internacionais ao projetar poder e gerar riqueza, sendo o IED parte constitutiva desse processo. Em termos proporcionais, o fluxo de investimentos chineses no sistema internacional começa sua trajetória a partir de $2005,{ }^{8}$ sendo considerável somente a partir de 2008 e tendo um aumento exponencial na década de 2010, quando o regime de acumulação da China inicia uma série de transformaçóes estruturais motivado por fatores externos, como o salto qualitativo do país nas cadeias globais de valor (Cintra e Pinto, 2017).

\section{GRÁFICO 4}

Evolução do IED da China (2005-2016)

(Em US\$ bilhões)

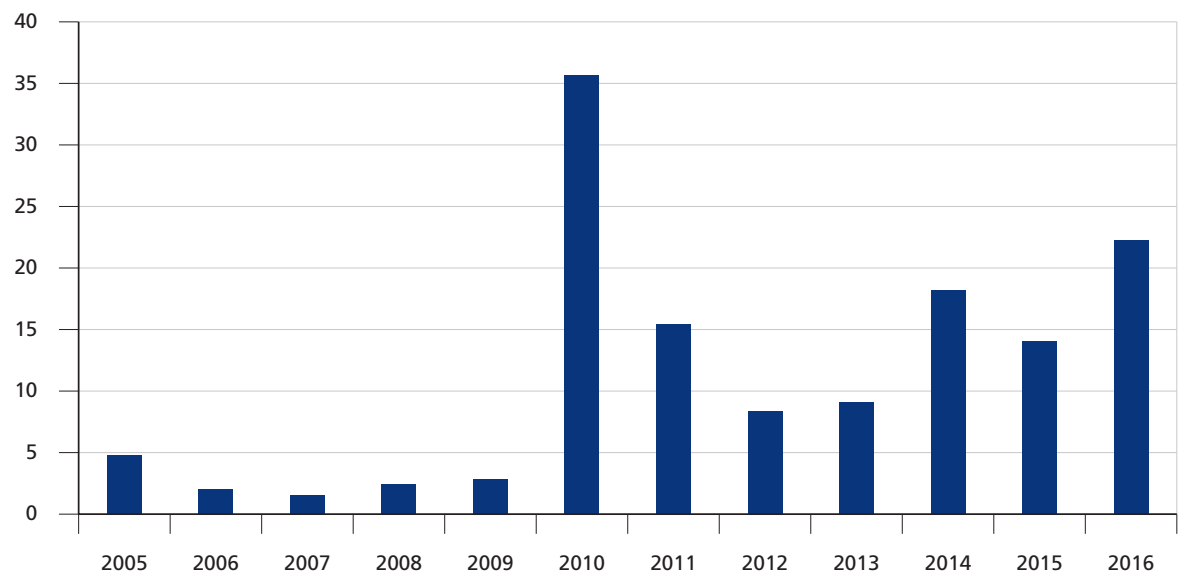

Fonte: Rodrigues e Hendler (2018)

Elaboração dos autores.

Recentemente, a China tem aumentado consideravelmente seus IEDs na região da América Latina e no Caribe, tornando a região um dos principais destinos a partir da década de 2010. Isso se deve particularmente à sinergia entre a demanda chinesa e a oferta latino-americana no que tange aos recursos naturais e, como resultado, é provável que o IED continue a crescer a um ritmo constante nos próximos anos (Shambaugh, 2013).

8. Dessa forma, apesar de o horizonte temporal estabelecido neste trabalho ser de 2001 a 2016, os gráficos de IED utilizados para a América Latina serão iniciados a partir de 2005, haja vista que o montante prévio é irrisório e não modificaria a análise objetiva do estudo. 
Vários fatores vêm afetando essas tendências de atuação chinesa na América Latina. Entre elas, destacam-se a saturação do capital de investimento no mercado doméstico chinês e a disponibilidade de divisas do país, levando as empresas a buscar no exterior novas oportunidades em países que necessitam de investimentos, como é frequente na região. $\mathrm{O}$ acesso a crédito bancário e financiamento estatal são outras determinantes facilitadoras.

O principal interesse dos IEDs chineses na América Latina está claramente voltado para o setor de energia (mais especificamente o de hidrocarbonetos, seguido pela mineração, com cobre e ferro, e outras diversas atividades primárias). Do total acumulado de US\$136,84 bilhōes de IED chinês na América Latina no período 2005-2016, a concentraçấo nesse setor foi de 59,438\%, dos quais a maior parte foi para o segmento de petróleo, em acordos feitos com Brasil, Equador e Venezuela. As açóes de outras áreas de atuação das empresas chinesas no continente foram: 19,20\% em metais; e 6,875\% no setor de transportes (gráfico 5).

\section{GRÁFICO 5}

\section{Distribuição do IED e ativos acumulados da China na América Latina} (Em \%)
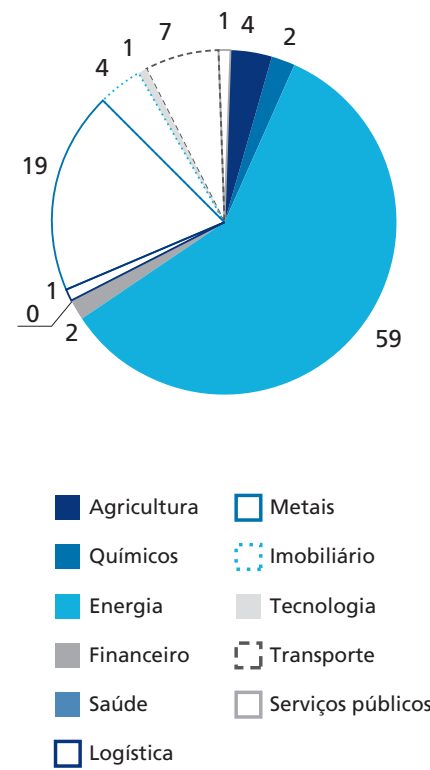

Fonte: AEI e Heritage Foundation (2016)

Elaboração dos autores.

Obs.: Total: US\$136.84 bilhões.

Pode-se dizer que o perfil dos IEDs chineses na regiáo possui a seguinte natureza: i) orientação a longo prazo e segurança de recursos; ii) estabelecimento 
de empresas chinesas com pouca ou nenhuma transferência de tecnologia para os países de destino; iii) ausência de condicionalidades políticas; iv) ausência de promoção de uma agenda específica pela China; e v) obras de infraestrutura que trazem consigo a obrigatoriedade de assinatura de empresas do país asiático (Slipak, 2014; Svampa e Slipak, 2015). Esses fluxos destinam-se, portanto, apenas à compra de matérias-primas, formação de joint ventures para aquisição de licenças para exploração de recursos naturais, fusóes e aquisiçóes de ativos por meio de grandes grupos estatais (Ray e Gallagher, 2017) e, nos casos de obras de infraestrutura, para o desempenho de empresas transnacionais e estatais chinesas para a construção de corredores de exportação que facilitem o escoamento mais eficiente dos recursos naturais.

Gallagher e Porzecanski (2010) realizam uma interessante distinção acerca dos diferentes focos de interesse na busca chinesa por recursos naturais. A primeira, denominada de resource seeking (busca de recursos), seria uma forma de garantir fontes de matérias-primas, energia e alimentos; a segunda, market seeking (busca de mercado), teria o intuito de consolidar a indústria do país como altamente competitiva e voltada para economias globais; e a terceira, efficiency seeking (busca de eficiência), consiste em uma atuação visando à diversificação (Leite e Ramos, 2016; Vadell, 2011). Majoritariamente, o IED destinado à região faz parte do primeiro tipo, destinado à exploração de setores estratégicos no país asiático, como cobre, aço, petróleo e soja.

Segundo Rodrigues e Hendler (2018, p. 23), mais de 90\% das empresas que investiram na América do Sul são estatais, indicando o papel geoestratégico do Estado chinês na realização e direcionamento dos IEDs de acordo com seus interesses nacionais. Em outros termos, a China vem expandindo sua influência pelo mundo por meio dos IEDs, ocupando importantes posiçóes no tabuleiro do jogo internacional de poder.

No que tange aos dados de IED chinês para a América Latina, segundo dados do China Global Investment Tracker para o período de 2005-2016, aproximadamente $95 \%$ dos investimentos para a regiáo são realizados no subcontinente sul-americano, com IEDs pontuais em países como México, com US \$ 2,12 bilhóes, Trinidad e Tobago, com US\$ 1,17 bilhão e Panamá, com US\$ 900 milhóes. Dessa forma, justifica-se a análise subsequente dos dados a ser realizada somente para os países da América do Sul.

Da mesma forma, constata-se que, no acumulado de 2005-2016, o Brasil desponta como maior receptor de IED na América do Sul, com US\$ 52.210 bilhóes, seguido da Argentina, com US\$27.460 bilhóes, Venezuela, com US\$20.610 bilhôes, Peru, com US\$ 19.670 bilhóes, Equador, com US\$14.730 bilhóes, 
Bolívia, com US\$ 4.100 bilhões, Chile, com US\$ 2.860 bilhões, e Colômbia, com US\$ 2.170 bilhões.

GRÁFICO 6

IED da China na América do Sul por país

(Em \%)
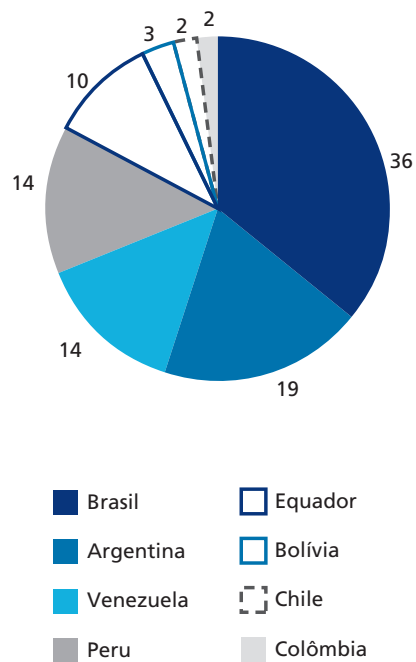

Fonte: AEl e Heritage Foundation (2016)

Nesse cenário, os países latino-americanos intensificam sua dependência na dinâmica do comércio internacional e de suas flutuações de preços, provocando incertezas em relação ao crescimento e ao balanço de pagamentos. Uma vez que as possibilidades de desenvolvimento econômico estáo fortemente ligadas à transformação radical de estruturas produtivas para superar gargalos e rigidez do subdesenvolvimento (Furtado, 2000), o processo de industrialização é imprescindível na promoção da produtividade de maneira longa e sustentada, com maior emprego, renda e sofisticação tecnológica.

No caso específico das relaçóes sino-latino-americanas, esse processo perpetua uma lógica cooperativa e deletéria de assimetria estrutural que foi criada entre ambas as regióes (Katz, 2016). Assim, os IEDs se manifestam numa dualidade entre os benefícios econômicos imediatos e a preterição dos desafios para o desenvolvimento de médio-longo prazo, minimizando-se a percepção das vulnerabilidades domésticas e da geração de uma relaçáo assimétrica e de dependência.

Significa dizer que, apesar dos benefícios econômicos que os IEDs trazem para os países latino-americanos em áreas sensíveis no curto prazo, não tendem a desenvolver capacidades industriais, ou atividades intensivas em conhecimento 
tecnológico, reforçando barreiras econômicas e políticas ao desenvolvimento de médio e longo prazo. Dessa forma, o direcionamento das empresas chinesas para o setor de commodities fortalece e aprofunda as atividades extrativistas de baixo valor agregado e reforça o caráter de reprimarizaçáo das economias regionais. Além disso, em termos de investimentos em infraestrutura em portos, estradas, ferrovias, é benévolo para a região diminuir custos, reduzir gargalos logísticos e aprimorar a competitividade, ainda que a estrutura dos projetos seja totalmente voltada para o favorecimento do desenvolvimento chinês e não para o fortalecimento interno e integrado das economias latino-americanas, facilitando a consecução de corredores de exportação em vez de corredores de integração, tal como delineados pelos projetos do Conselho Sul-Americano de Infraestrutura e Planejamento (Cosiplan) e pelo projeto da ferrovia Transamazônica.

\section{CONCLUSÕES}

A presença chinesa na LAC está se expandindo e se solidificando ao longo dos anos e, ao mesmo tempo que sua inserção na regiáo traz benefícios econômicos e até mesmo políticos, esse processo também possui um ônus para os países latinos. Nesse contexto, a integração regional é um mecanismo importante para se pensar a exequibilidade do fortalecimento da regiáo frente ao cenário internacional, aumentando a capacidade de barganha dos países latinos perante as grandes potências.

Consequentemente, nessa nova ordem mundial, é crucial compreender as características dos vínculos dos Estados latino-americanos com a China, uma vez que a regiâo atende aos objetivos geopolíticos da nova política externa chinesa de transformação do sistema internacional. Portanto, é de extrema importância que os governos e tomadores de decisão latino-americanos estabeleçam condiçóes e acordos institucionais mais rigorosos, a fim de garantir que as relaçóes comerciais, os IEDs e os acordos bilaterais e multilaterais também incluam, em certa medida, transferências de tecnologias e conhecimento, criação de incentivos para o escoamento de produtos manufaturados da região para o mercado asiático e projetos estratégicos que promovam um interdependência menos assimétrica entre os países.

Apesar do aumento do comércio e das relaçóes econômicas entre os países, com o estímulo a interdependência e financiamento de projetos de infraestrutura que são essenciais para a região, o aumento dos preços médios das commodities no início do século XXI fez com que a LAC tendesse cada vez mais a gravitar em torno da economia chinesa e se inserisse na economia global como fornecedora de commodities e bens manufaturados de baixo valor agregado, reafirmando uma inserção dependente e subordinada no sistema capitalista (Corsi, Santos e Camargo, 2019). 
A integração econômica é indispensável para integração à economia mundial, evitando o isolamento e a dispersão. Nesse sentido, para que haja uma maior institucionalidade da integração e sua relação com o aprofundamento dos processos, é necessário estimular a reflexão sobre os impactos político-econômicos da cooperaçáo e integração nos espaços latino-americanos, assim como as perspectivas de longo prazo desse processo num cenário globalizado e que, gradativamente, tem a China como um de seus principais interlocutores.

Em suma, pode ser verdade que quando todas as flores estiverem florescendo a primavera será bela, mas é preciso observar se a forma como algumas flores estão sendo cultivadas é capaz de fazê-las florescer de forma tão bela quanto as demais. Além disso, é preciso ter uma visão crítica sobre se a China está ou não permitindo/promovendo o desenvolvimento dos países latino-americanos. Afinal, ao contrário do que se pode imaginar, por serem países do Sul Global, as relações LAC-China são muito assimétricas.

\section{REFERÊNCIAS}

AEI-AMERICAN ENTERPRISE INSTITUTE; HERITAGE FOUNDATION. China Global Investment Tracker. Washington: AEI; Heritage Foundation, 2016. ALMEIDA, P. R. de. O contexto geopolítico da América do Sul: visão estratégica da integração regional. Meridiano 47, v. 7, n. 76, p. 15-23, 2006.

CARMO, C. A. do; PECEQUILO, C. S. O Brasil e o vácuo de liderança regional: o avanço sino-americano (2011/2016). Austral: Revista Brasileira de Estratégia e Relaçóes Internacionais, v. 5, n. 9, p. 54-75, 2016.

CHINA'S growth benefits Chile copper export report. China FTA Network, 31 Oct. 2009. Disponível em: <http://fta.mofcom.gov.cn/enarticle/enchile/ enchilenews/200911/1595_1.html>.

CHINA-COSTA RICA FTA entered into force on August 1. China FTA Network, 3 Aug. 2011. Disponível em: <http:/fta.mofcom.gov.cn/enarticle/ encosta/encostanews/201108/7440_1.html>.

CHINA-PERU FTA entered into force on March 1. China FTA Network, 1 Mar. 2010. Disponível em: <http://fta.mofcom.gov.cn/enarticle/enperu/ enperunews/201003/2241_1.html>.

CINTRA, M. A. M; PINTO, E. C. China em transformação: transição e estratégias de desenvolvimento. Revista de Economia Política, v. 37, n. 2, p. 381-400, 2017.

CORSI, F. L.; SANTOS, A. dos; CAMARGO, J. M. A América Latina: ciclo de commodities e crise do capitalismo global. Austral: Revista Brasileira de Estratégia e Relaçóes Internacionais, v. 8, n. 15, p. 168-194, jan.-jun. 2019. 
CURADO, M. China rising: threats and opportunities for Brazil. Latin American Perspectives, v. 42, n. 6, p. 88-104, 2015.

CYPHER, J. M.; WILSON, T. D. China and Latin America: processes and paradoxes. Latin American Perspectives, v. 42, n. 6, p. 5-26, 2015.

DEZAN SHIRA AND ASSOCIATES. China-Chile free trade agreement. [s. 1.]: Asia Briefing, 2005. Disponível em: <https://www.origin-gi.com/images/ GI_database/China_Chile_FTA_1.pdf>. Acesso em: 10 ago. 2018.

China-Peru free trade agreement. [s. 1.]: Asia Briefing, 2009. Disponível em: < https://tinyurl.com/y6fo6aet>.

ESTEVADEORDAL, A.; MOREIRA, M. M.; KAHN, T. LAC investment in China: a new chapter in Latin America and the Caribbean-China relations. [s. l.]: IDB, 2014.

FURTADO, C. Formação econômica da América Latina. 2. ed. Rio de Janeiro: Lia, 1970.

Desenvolvimento e subdesenvolvimento. In: BIELSCHOWSKY, R. (Org.). Cinquenta anos de pensamento na Cepal. Rio de Janeiro: Record, 2000. p. 239-262. v. 2.

GALLAGHER, K. P. The China triangle: Latin America's China boom and the fate of the Washington Consensus. New York: Oxford University Press, 2016.

GONZÁLEZ, A. Latin America-China trade and investment amid global tensions: a need to upgrade and diversify. Washington: Atlantic Council, 2018.

HARRIS, R. L. China's relations with the Latin American and Caribbean countries: a peaceful panda bear instead of a roaring dragon. Latin American Perspectives, v. 42, n.6, p. 153-190, 2015.

HIRATUKA, C. Changes in the Chinese development strategy after the global crisis and its impacts in Latin America. Revista de Economia Contemporânea, v. 22, n. 1, p. 1-25, 2018. Disponível em: <https://revistas.ufrj.br/index.php/rec/ article/view/20625>.

HUI, L. Full text: Keynote speech by President Xi Jinping at the opening ceremony of the 1st China International Import Expo. Xinhuanet, 5 Nov. 2018. Disponível em: <http://www.xinhuanet.com/english/2018-11/05/c_137583815.htm>.

JENKINS, R. Is Chinese competition causing deindustrialization in Brazil? Latin American Perspectives, v. 42, n. 6, p. 42-63, 2015.

JENKINS, R. Latin America and China: a new dependency? Third World Quarterly, v. 33, n. 7, p. 1337-1358, 2012. 
JWG - JOINT WORKING GROUP. China-Costa Rica free trade agreement joint feasibility study. [s. 1.]: [s. n.], 2008. Disponível em: <http://fta.mofcom. gov.cn/costarica/yanjiubaogao_en.pdf>.

KATZ, Claudio. Neoliberalismo, Neodesarrollismo, Socialismo. Buenos Aires: Batalla de Ideas, 2016.

KELLY, P. Checkerboards and Shatterbelts: the geopolitics of South America. Austin: University of Texas Press, 1997.

LEITE, A. C. C.; RAMOS, L. G. S. O. Investimentos chineses na América do Sul: um desenho das preferências de destino e setores. In: LIMA, M. C. (Org.). Perspectivas asiáticas. Rio de Janeiro: Cicef; Folio Digital, 2016. p. 165-192. v. 6. (Coleção Pensamento Crítico).

MEDEIROS, C. A. de; CINTRA, M. R. V. P. Impacto da ascensão chinesa sobre os países latino-americanos. Revista de Economia Política, v. 35, n. 1, p. 28-42, 2015.

MELO, M. C. P. de; AMARAL FILHO J. do. The political economy of Brazil-China trade relations, 2000-2010. Latin American Perspectives, v. 42, n. 6, p. 64-87, 2015.

PADULA, R. Integraçáo regional de infraestrutura e comércio na América do Sul nos anos 2000: uma análise político-estratégica. 2010. Tese (Doutorado) - Universidade Federal do Rio de Janeiro, Rio de Janeiro, 2010.

PETERS, E. D. Recent China-LAC trade relations: implications for inequality? Berlin: Desigualdades.net, 2013. p. 1-27. (Working Paper, n. 40).

RAY, R.; GALLAGHER, K. P. China-Latin America economic bulletin. Boston: Boston University Press, Gegi, 2017. (Discussion Paper, n. 2017-1).

RAY, R.; WANG, K. China-Latin America economic bulletin, 2019 edition. Boston: Boston University Press, 2019.

RODRIGUES, B. S.; HENDLER, B. Investimento externo chinês na América Latina e no sudeste asiático: uma análise de escopo, valores e setores-alvo. Estudos Internacionais, v. 6, n. 3, p. 5-25, 2018.

ROSALES, O.; KUWAYAMA, M. China and Latin America and the Caribbean: building a strategic economic and trade relationship. Santiago: Eclac, 2012.

SANTOS, T. Integraçáo energética da América do Sul: desdobramentos do desenvolvimento institucional. 2014. Dissertação (Mestrado) - Pontifícia Universidade Católica do Rio de Janeiro, Rio de Janeiro, 2014.

Regional energy security: re-evaluating concepts and policies to promote energy integration in Mercosur. 2018. Tese (Doutorado) - Universidade Federal do Rio de Janeiro, Rio de Janeiro, 2018. 
SEVARES, J. China: un socio imperial para Argentina y América Latina. Buenos Aires: Edhasa, 2015.

SHAMBAUGH, D. China goes global: the partial power. New York: Oxford University Press, 2013.

SLIPAK, A. M. América Latina y China: cooperación Sur-Sur o Consenso de Beijing? Nueva Sociedad, v. 250, p. 102-113, mar.-abr. 2014.

SVAMPA, M.; SLIPAK, A. M. China en América Latina: del Consenso de los Commodities al Consenso de Beijing. Revista Ensambles, n. 3, p. 34-63, 2015.

THE PROTOCOL upgrading China-Chile free trade agreement comes into force today. China FTA Network, 1 Mar. 2019. Disponível em: <http://fta. mofcom.gov.cn/enarticle/enchile/enchilenews/201903/39927_1.html>.

TRASPADINI, R; STEDILE, J. P. (Org.). Ruy Mauro Marini: vida e obra. 2. ed. São Paulo: Expressão Popular, 2011.

VADELL, J. A China na América do Sul e as implicaçóes geopolíticas do Consenso do Pacífico. Revista de Sociologia e Política, v. 19, p. 57-79, 2011.

WITS. World Integrated Trade Solutions. Worldbank Database. Disponível em: <https://wits.worldbank.org/> Acesso em 10 de janeiro de 2020. 
